\title{
Pull-Out Resistance Capacity of a New Perfobond Shear Connector for Steel Pile Cap Strengthening
}

\author{
Young-Ho Kim, ${ }^{1}$ Jae-Yoon Kang, ${ }^{2}$ Hyun-Bon Koo, ${ }^{2}$ and Dae-Jin Kim ${ }^{3}$ \\ ${ }^{1}$ Institute of R\&D, Ji Seung Consultant Co., Ltd., Seoul 06128, Republic of Korea \\ ${ }^{2}$ Korea Institute of Civil Engineering and Building Technology, Goyang 10223, Republic of Korea \\ ${ }^{3}$ Department of Architectural Engineering, Kyung Hee University, Yongin 17104, Republic of Korea
}

Correspondence should be addressed to Dae-Jin Kim; djkim@khu.ac.kr

Received 9 November 2015; Accepted 3 January 2016

Academic Editor: Akihiko Kimura

Copyright (C) 2016 Young-Ho Kim et al. This is an open access article distributed under the Creative Commons Attribution License, which permits unrestricted use, distribution, and reproduction in any medium, provided the original work is properly cited.

\begin{abstract}
This study proposes a new type of the perfobond shear connector, which can be used to strengthen the steel pile cap embedded into the structure foundation, and evaluates its pull-out resistance capacity by performing a test on ten specimens. Test parameters include the embedment length of the shear connector, existence of transverse rebars passing through holes in the shear connector, and their shape, size, and number. The pull-out load versus slip curve is plotted for all specimens, and their failure modes are identified. The effects of the test parameters on the peak pull-out load are examined in this work. The test results show that the perfobond shear connector proposed in this study can retain the peak pull-out load up to 6 times higher than the one without any holes. This indicates that the existence of holes in the shear connector enables the dowel action of concrete inside the hole, resulting in the improvement of the shear resistance capacity of the connector.
\end{abstract}

\section{Introduction}

At the foundation to support an upper structure, there exists a connection between piles and concrete footing as illustrated in Figure 1. The integration of these two structural components is very important to guarantee the safe load transfer from the upper structure to the supporting layer of rocks. In general, this can be achieved by the use of steel reinforcing bars embedded into the concrete footing. In this case, the bond between the steel rebars and concrete is activated by the mechanical bearing of bar ribs, and it is essential to retain a sufficient level of their bond strength. However, since their rib size is limited and they have relatively small cross-sectional area, their bond strength is also limited to a small value as indicated in various concrete design code provisions such as ACI building code [1] and Eurocode 2 [2].

In order to handle this issue, we propose a new perfobond shear connector illustrated in Figure 2, which can guarantee an excellent composite behavior among the structural components at the steel pile cap. Originally, this type of perfobond shear connectors was first developed by Zellner as a remedy to the fatigue problem of steel studs in the steel composite bridge [3]. This device is basically a steel plate with holes and embedded into concrete to ensure the perfect integration of steel members and the surrounding concrete. As external loads are applied, the dowel action of concrete inside the hole is activated and enables the load transfer between the structural components made of different materials. This perfobond shear connector has been known to retain higher shear strength, better fatigue performance, and more enhanced constructability than existing shear studs [4].

Several publications have investigated the performance of the perfobond shear connector. Veldanda and Hosain [5] compared the shear strengths of the perfobond shear connector and shear studs by performing a pull-out test on specimens with these types of connections. Oguejiofor and Hosain [6-8] performed a bending test on steel-concrete composite beams with perfobond shear connectors and proposed its shear strength equation. Sara and Bahram [4] modified the shear strength equation proposed by Oguejiofor and Hosain with the consideration of the bond strength at the steelconcrete interface. More recently, Machacek and Studnicka 


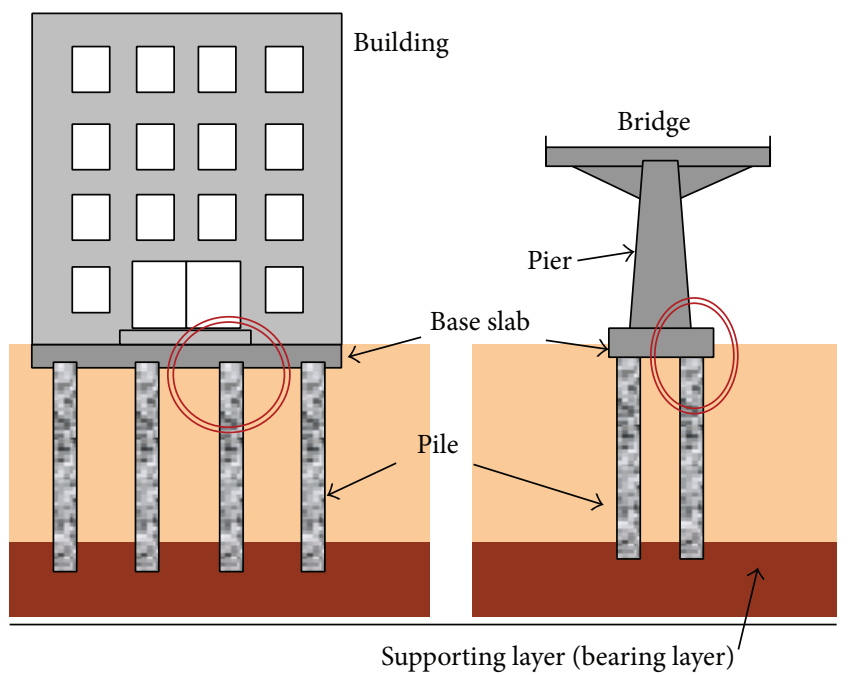

FIgURE 1: Connection between structural foundation and steel pile caps.

[9] and Valente and Cruz [10] examined the structural performance of the perfobond shear connector embedded into lightweight concrete, and still various kinds of research are performed on the development of its new details and application to different types of structural members.

This paper experimentally evaluates the shear strength of the proposed perfobond connector by performing a pull-out test on ten specimens by considering the embedment length of the shear connector, existence of transverse rebars passing through holes in the shear connector, and their shape, size, and number as test parameters. The failure characteristics of the test specimens are examined, and their load-displacement curves are analyzed. We also investigate the effects of the test variables on the pull-out strengths of the test specimens in order to demonstrate the effectiveness of the proposed perfobond shear connector.

\section{Experimental Program}

2.1. Test Specimens. For this study, ten specimens totally were manufactured and tested to investigate the effectiveness of the newly proposed perfobond rib shear connector. In all specimens, a perforated steel flat-plate with a sectional dimension of $100 \mathrm{~mm}$ by $8 \mathrm{~mm}$ was embedded in the concrete block. In six of the test specimens, the embedment length of the perforated flat-plate was $150 \mathrm{~mm}$, while it was $270 \mathrm{~mm}$ in other four flat-plates. The center of the perforated flat-plate coincides with that of the concrete block in all specimens. Figure 3 illustrates the geometrical configurations of the specimens described above.

Test parameters include the type (no hole, closed hole, and open hole), size $(40 \mathrm{~mm}, 50 \mathrm{~mm}$, and $60 \mathrm{~mm}$ ), number $(0,1$, and 2$)$ of holes, embedment length of the shear connector $(150 \mathrm{~mm}$ and $270 \mathrm{~mm}$ ), and existence of transverse rebars passing through holes. These parameters were determined by considering that, in general, the most effective hole size and distance between holes are approximately 0.45 and two

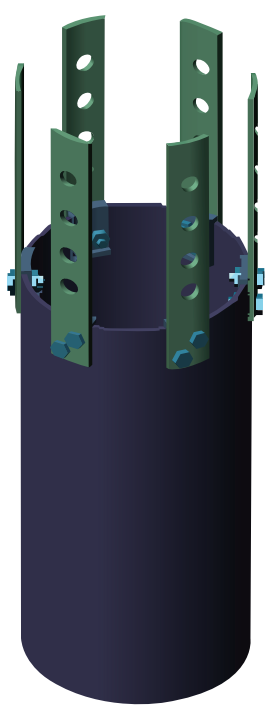

(a) Perfobond shear connector with closed holes

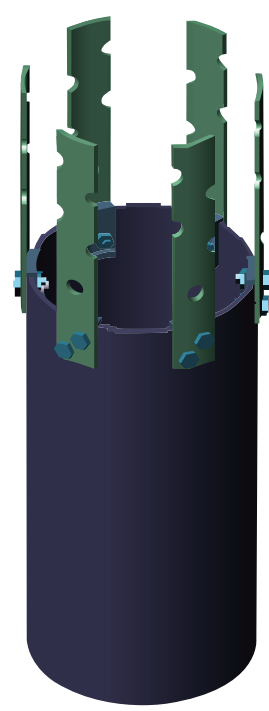

(b) Perfobond shear connector with open holes

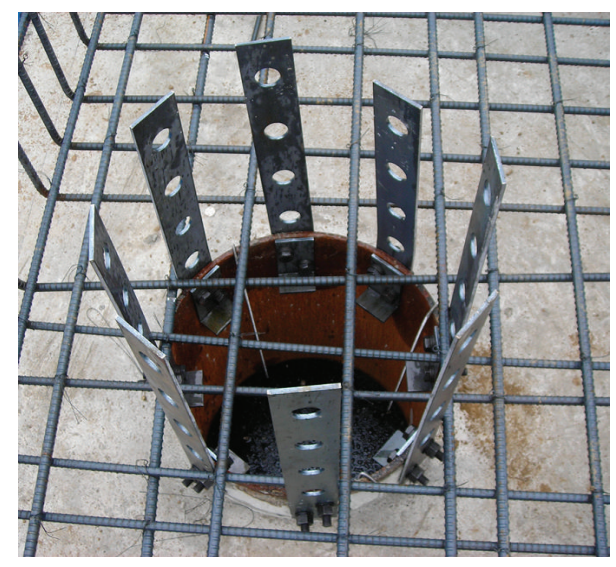

(c) Construction example of the proposed perfobond shear connector for steel pile cap strengthening

FIGURE 2: Strengthening of steel pile caps using the perfobond shear connectors.

times the width of the perfobond connector, respectively [11]. The shapes of the perfobond connectors used for the test specimens are provided in Figure 4. The details of the ten test specimens are summarized in Table 1. For convenience, the test specimens in the table are grouped into the four categories such as Series I, II, III, and IV. From the results of Series I and II, the effects of hole size and transverse rebars passing through holes on the shear resistance of the perfobond connector can be discussed, respectively. Similarly, the effects of the embedment length of the shear connector and types of holes can be analyzed from those of Series III and IV.

The compressive strength of concrete was measured in accordance with the standards of ASTM C39 9 [12] and the measured average strength was found to be $27.30(\mathrm{MPa})$. The yield strength, ultimate strength, and maximum strain at fracture of rebars are $490.1 \mathrm{MPa}, 584.9 \mathrm{MPa}$, and $18.1 \%$, 

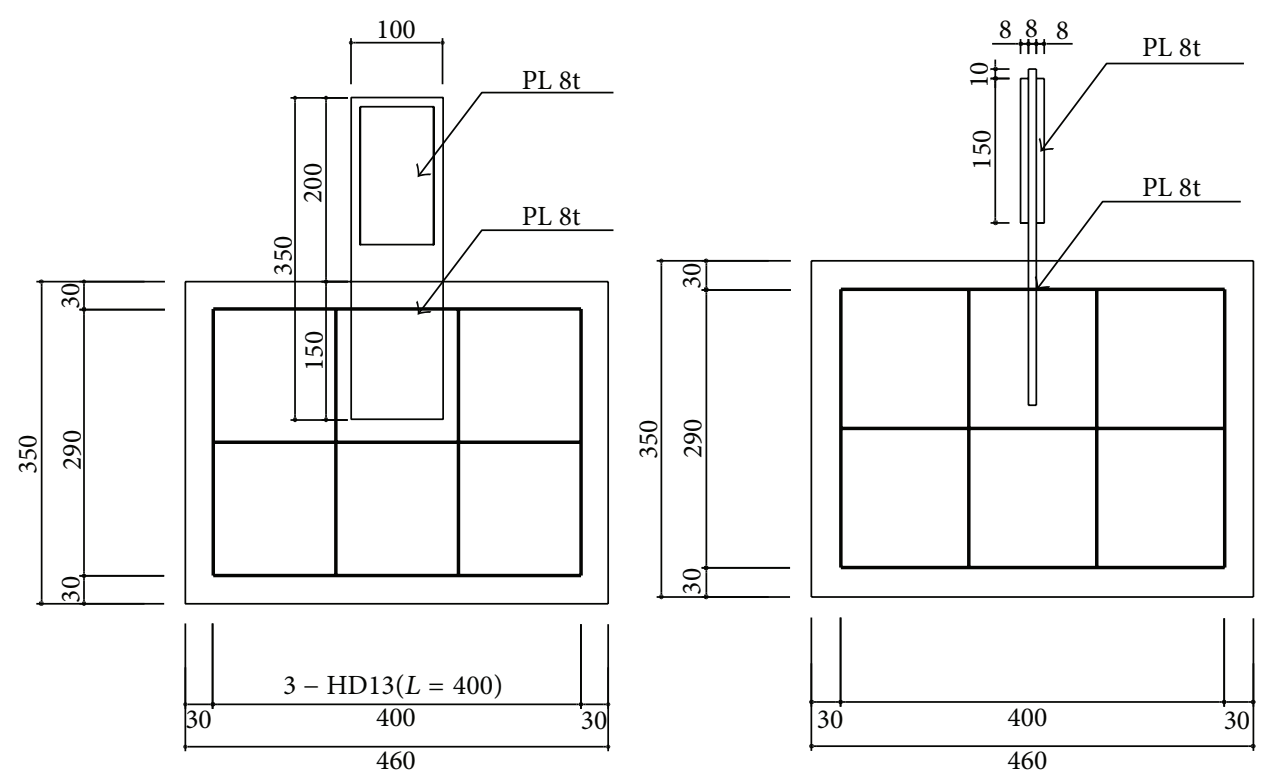

(a) Specimens with shear connector embedment length equal to $150 \mathrm{~mm}$
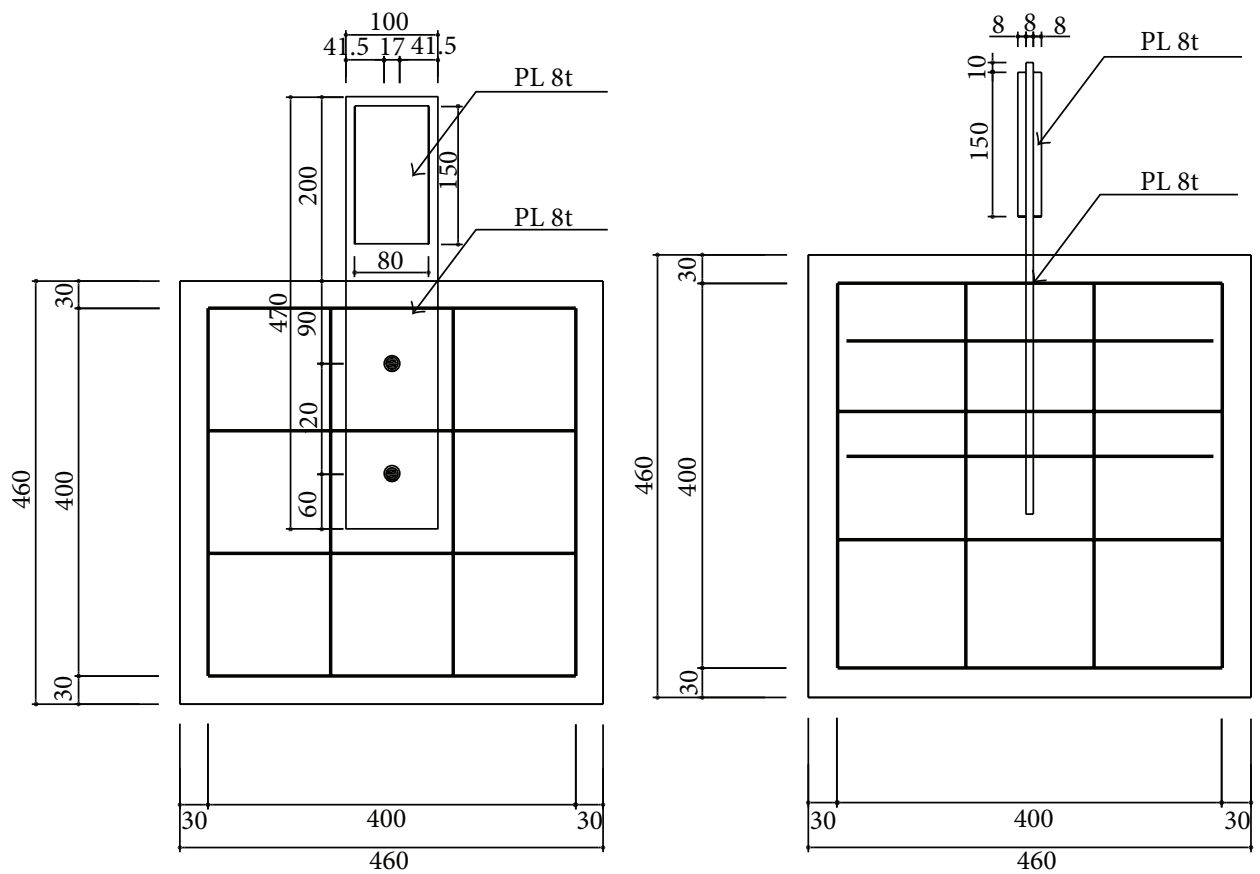

(b) Specimens with shear connector embedment length equal to $270 \mathrm{~mm}$

FIGURE 3: Size and rebar details of test specimens (unit: $\mathrm{mm}$ ).

respectively. The corresponding values of the steel plates are $321.4 \mathrm{MPa}$, $441.5 \mathrm{MPa}$, and $33.7 \%$, respectively. These properties are summarized in Table 2.

2.2. Testing Equipment and Procedure. Pull-out tests were conducted on the ten specimens to estimate the strength of the new perfobond shear connectors and to identify their failure modes. The test setup is shown in Figure 5. The test was conducted on a universal testing machine (UTM), which allows displacement-based load control. The maximum capacity of the UTM is $250 \mathrm{kN}$ and the load was applied to the specimen at a rate of $0.5 \mathrm{~mm} / \mathrm{min}$. The magnitude of loading was measured by the load cell attached at the bottom of the actuator. The vertical displacement was monitored by two linear variable differential transducers (LVDTs) installed near the specimen, and the concrete cube of the test specimen was fixed onto the UTM base by putting additional steel frames on the top of the concrete cube and connecting it to the UTM base using long bolts, as shown in Figure 5. The load-versus-displacement data were recorded 


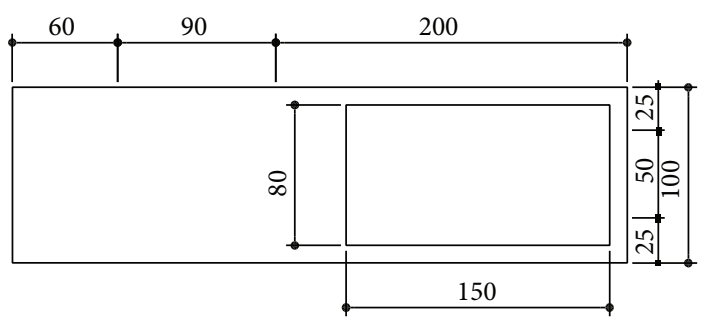

(a) Type with no holes

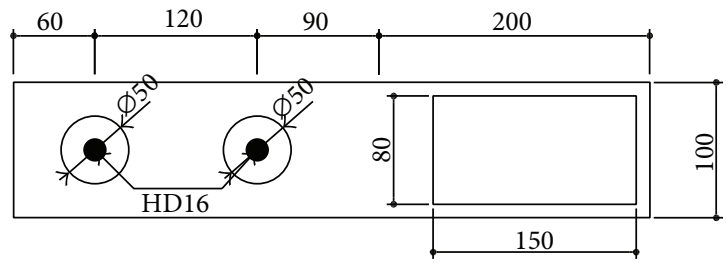

(c) Type with two closed holes

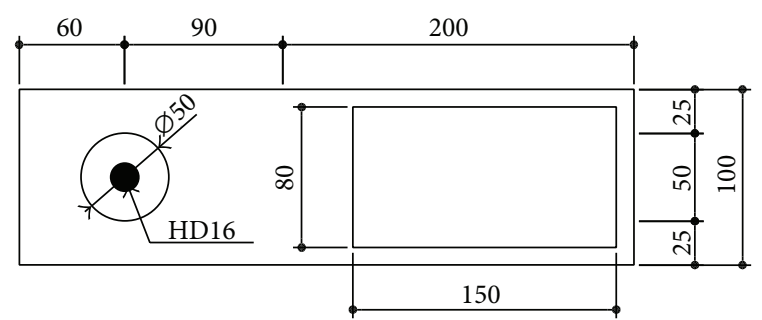

(b) Type with a single closed hole

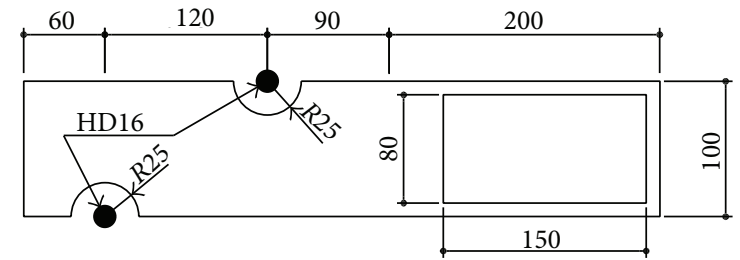

(d) Type with two open holes

FIGURE 4: Types of perfobond shear connectors (unit: $\mathrm{mm}$ ).

TABLE 1: Details of test specimens.

\begin{tabular}{|c|c|c|c|c|c|c|}
\hline & Specimen & $\begin{array}{l}\text { Type of } \\
\text { holes }\end{array}$ & $\begin{array}{c}\text { Diameter of } \\
\text { holes (unit: } \\
\mathrm{mm} \text { ) }\end{array}$ & $\begin{array}{l}\text { Number of } \\
\text { holes }\end{array}$ & $\begin{array}{l}\text { Embedment length of shear } \\
\text { connector (unit: } \mathrm{mm} \text { ) }\end{array}$ & $\begin{array}{l}\text { Total number of transverse } \\
\text { rebars passing through holes }\end{array}$ \\
\hline \multirow{3}{*}{ Series I } & PN-0015-N & No hole & $\mathrm{N} / \mathrm{A}$ & 0 & \multirow{3}{*}{150} & \multirow{3}{*}{0} \\
\hline & PO-5015-N & \multirow{2}{*}{ Closed } & 50 & \multirow{2}{*}{1} & & \\
\hline & PO-6015-N & & 60 & & & \\
\hline \multirow{3}{*}{ Series II } & PO-4015-R & \multirow{3}{*}{ Closed } & 40 & \multirow{3}{*}{1} & \multirow{3}{*}{150} & \multirow{3}{*}{1} \\
\hline & PO-5015-R & & 50 & & & \\
\hline & PO-6015-R & & 60 & & & \\
\hline \multirow{2}{*}{ Series III } & PO-5027-N & \multirow{2}{*}{ Closed } & \multirow{2}{*}{50} & \multirow{2}{*}{2} & \multirow{2}{*}{270} & 0 \\
\hline & PO-5027-R & & & & & 2 \\
\hline \multirow{2}{*}{ Series IV } & PU-5027-N & \multirow{2}{*}{ Open } & \multirow{2}{*}{50} & \multirow{2}{*}{2} & \multirow{2}{*}{270} & 0 \\
\hline & PU-5027-R & & & & & 2 \\
\hline
\end{tabular}

throughout the entire loading history using a computer-aided data acquisition system.

\section{Pull-Out Resistance of the Perfobond Shear Connector}

3.1. General Behavior and Failure Modes. Table 3 summarizes the test results such as peak loads, displacements at peak loads, and loads corresponding to several crack propagation phenomena occurring in the concrete block. Figure 6 plots the load-displacement curves of the four series of the test specimens listed in Table 1 . Crack propagation patterns were basically similar in all of the test specimens, but the amount and range of cracking were different in each specimen. The failure characteristics of the test specimens include the yielding and fracture of the perforated flat-plate, its pull-out failure, and concrete delamination and are summarized in Table 4. Depending on the three characteristics, the ultimate failure modes of the test specimens can be categorized into five groups (Types I to V).

Figure 7 shows the cracking pattern of specimen PN0015-N on its top and side faces. It indicates that the specimen failed by bond-slip failure between the flat-plate steel shear connector and the surrounding concrete without any delamination or cracking of concrete. It seems to happen due to insufficient bond strength capacity of the steel shear connector without any holes, and this type of failure mode is categorized as Type I.

The cracking pattern of specimen $\mathrm{PO}-6015-\mathrm{N}$ is given in Figure 8. In this specimen, the pull-out force applied was initially resisted by the dowel action of the concrete inside the hole of the perfobond shear connector. However, as the load increases, the local bearing pressure on the concrete inside hole also increases, and this finally resulted in its crushing failure. Similar to the case of specimen PN-0015-N, the fracture of the steel perfobond shear connector did not occur, and no significant cracking of concrete was observed outside 


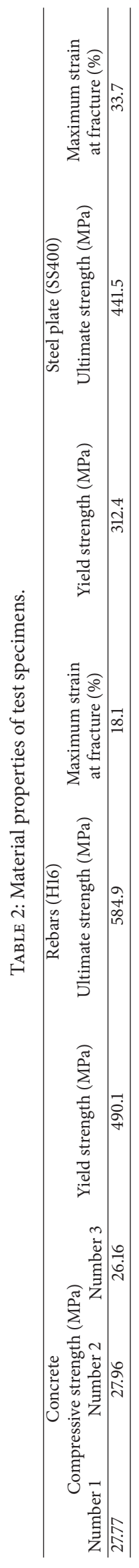




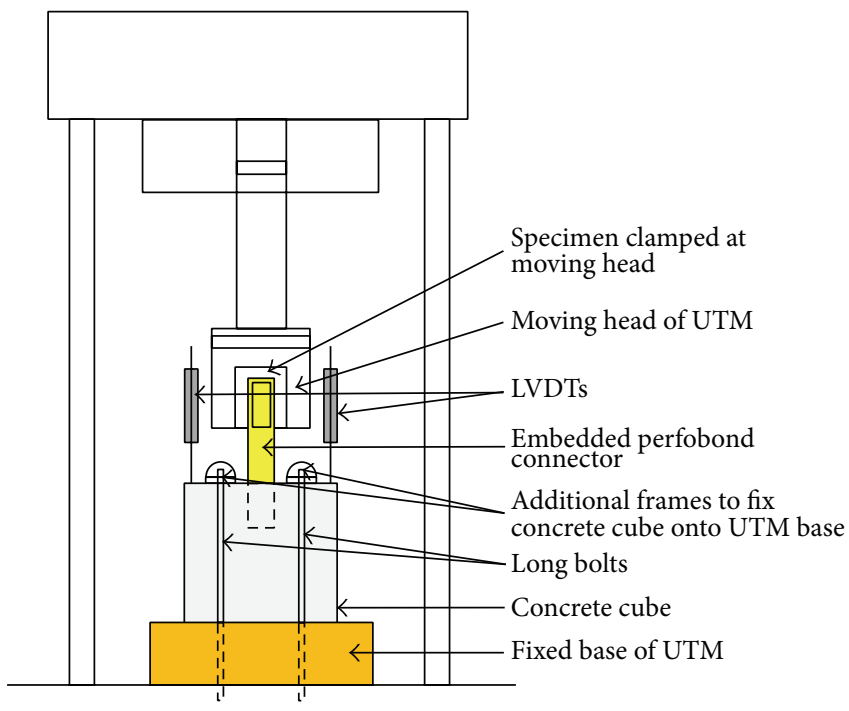

(a)

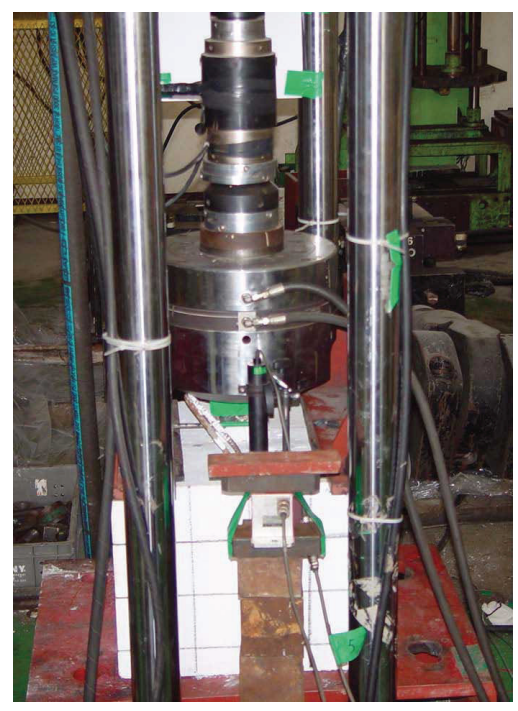

(b)

Figure 5: Test setup.

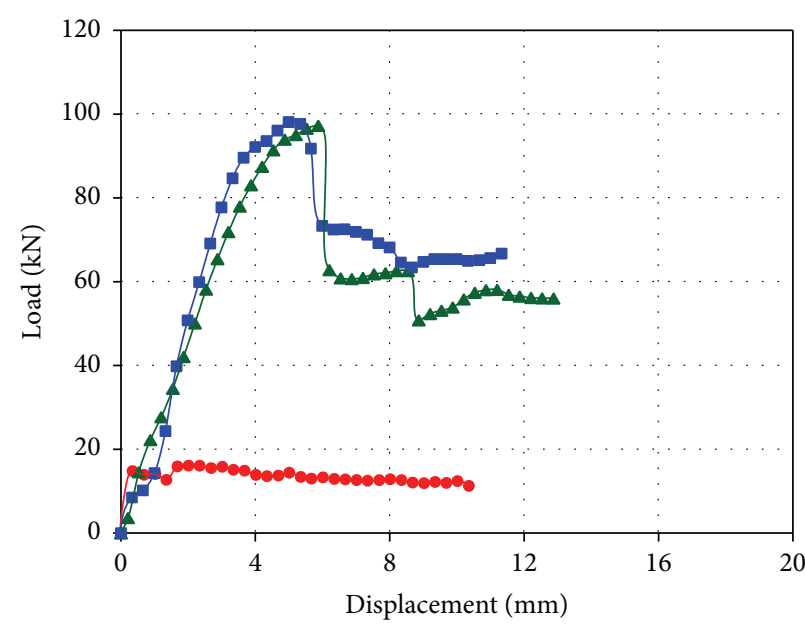

- PO-0015-N

\ PO-5015-N

- PO-6015-N

(a) Series I

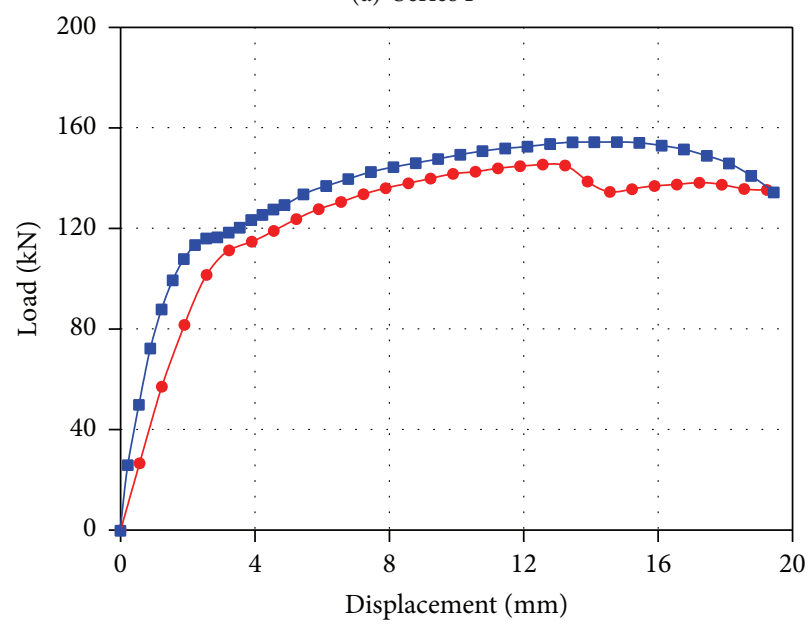

- PO-5027-N

- PO-5027-R

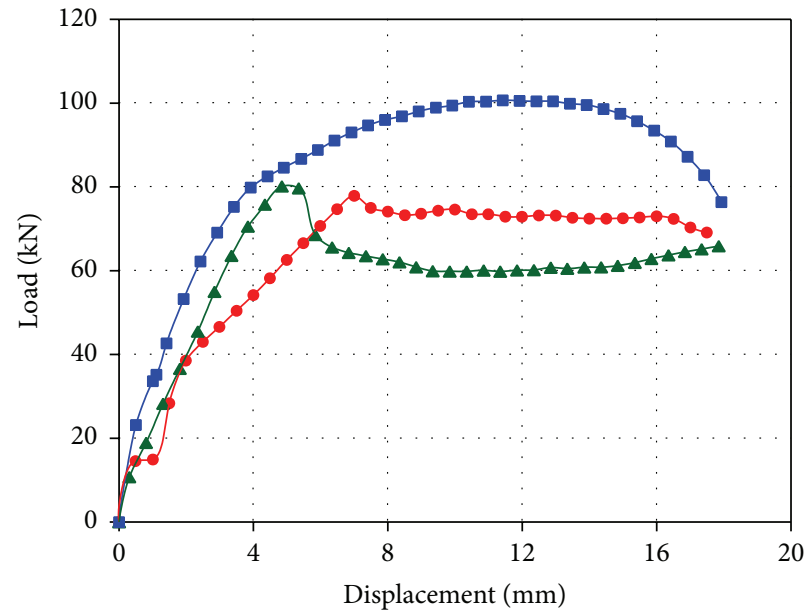

- PO-4015-R

- PO-5015-R

a PO-6015-R

(b) Series II

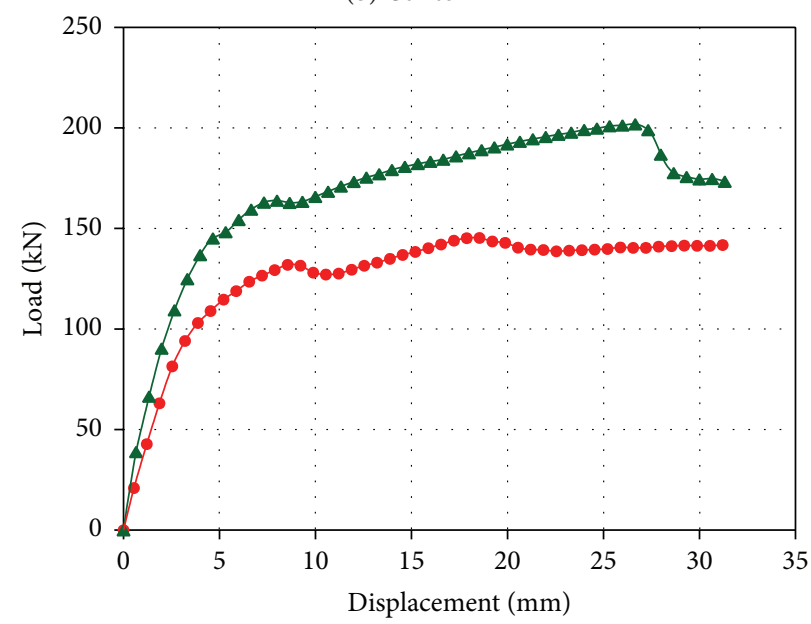

- PU-5027-N

- PU-5027-R

(c) Series III

(d) Series IV

FIGURE 6: Load-displacement curves of test specimens. 
TABLE 3: Results of the pull-out test.

\begin{tabular}{|c|c|c|c|c|c|}
\hline \multirow{2}{*}{ Specimen } & \multirow{2}{*}{ Peak load $(\mathrm{kN})$} & \multirow{2}{*}{$\begin{array}{l}\text { Displacement at } \\
\text { peak load }(\mathrm{mm})\end{array}$} & \multicolumn{3}{|c|}{ Cracking load $(\mathrm{kN})$} \\
\hline & & & $\begin{array}{l}\text { Cracking on top of } \\
\text { the concrete block }\end{array}$ & $\begin{array}{l}\text { Vertical cracking on the } \\
\text { side of the concrete block }\end{array}$ & $\begin{array}{l}\text { Horizontal cracking on the } \\
\text { side of the concrete block }\end{array}$ \\
\hline PN-0015-N & 16.6 & 1.95 & 15 & $\mathrm{~N} / \mathrm{A}$ & N/A \\
\hline PO-5015-N & 97.4 & 5.94 & 48 & 97 & 97 \\
\hline PO-6015-N & 99.2 & 5.20 & 76 & 88 & 94 \\
\hline PO-4015-R & 78.3 & 7.13 & 64 & 78 & $\mathrm{~N} / \mathrm{A}$ \\
\hline PO-5015-R & 81.3 & 5.21 & 33 & 69 & 69 \\
\hline PO-6015-R & 100.8 & 12.02 & 36 & $\mathrm{~N} / \mathrm{A}$ & $\mathrm{N} / \mathrm{A}$ \\
\hline PO-5027-N & 145.6 & 12.73 & 85 & 141 & $\mathrm{~N} / \mathrm{A}$ \\
\hline PO-5027-R & 154.7 & 14.40 & 130 & 135 & $\mathrm{~N} / \mathrm{A}$ \\
\hline PU-5027-N & 146.1 & 37.48 & 118 & 136 & $\mathrm{~N} / \mathrm{A}$ \\
\hline PU-5027-R & 202.2 & 26.76 & 148 & 153 & 153 \\
\hline
\end{tabular}

TABLE 4: Failure modes of test specimens.

\begin{tabular}{lcccc}
\hline Specimen & $\begin{array}{c}\text { Concrete delamination } \\
\text { and cracking }\end{array}$ & $\begin{array}{c}\text { Failure characteristics } \\
\text { Yielding and fracture of the } \\
\text { steel flat-plate shear connector }\end{array}$ & $\begin{array}{c}\text { Pull-out of the } \\
\text { perforated flat-plate }\end{array}$ & Ultimate failure mode \\
\hline PN-0015-N & $\mathrm{X}$ & $\mathrm{X}$ & $\mathrm{O}$ & Type I \\
PO-5015-N & $\mathrm{X}$ & $\mathrm{X}$ & $\mathrm{O}$ & Type II \\
PO-6015-N & $\mathrm{X}$ & $\mathrm{X}$ & $\mathrm{O}$ & Type III \\
PO-4015-R & $\mathrm{O}$ & $\mathrm{X}$ & $\mathrm{O}$ & \\
PO-5015-R & $\mathrm{O}$ & $\mathrm{X}$ & $\mathrm{X}$ & Type IV \\
PO-6015-R & $\mathrm{X}$ & $\mathrm{O}$ & $\mathrm{X}$ & \\
PO-5027-N & $\mathrm{X}$ & $\mathrm{O}$ & $\mathrm{X}$ & \\
PO-5027-R & $\mathrm{X}$ & $\mathrm{O}$ & $\mathrm{X}$ & Type V \\
PU-5027-N & $\mathrm{X}$ & $\mathrm{O}$ & $\mathrm{O}$ & \\
PU-5027-R & $\mathrm{O}$ &
\end{tabular}

the specimen. This type of failure occurred in specimens PO-5015-N and PO-6015-N, where no transverse rebars into the hole of the perfobond shear connector exist, and it is categorized as Type II.

The failure mode of specimen PO-5015-R is shown in Figure 9. In contrast to the case of Type II, the pull-out load is sustained by the dowel action of both the transverse rebar and the concrete inside the hole in this case. As a result, instead of exhibiting local crushing failure in the concrete inside the hole, a significant amount of cracking was observed outside the specimen at its ultimate stage. No yielding and fracture of the steel perfobond shear connector happened. This type of failure was observed in specimens PO-4015-R and PO-5015-R and is categorized as Type III.

Figure 10 shows the cracking pattern and failure mode of specimen PO-6015-R. In this specimen, the perfect bond between the shear connector and surrounding concrete was achieved mainly due to the shear resistance by the shear connector with sufficient embedment length and dowel action by both the transverse rebars and the concrete inside the holes of the shear connector. As a result, its failure mode at ultimate stage was characterized by the yielding and fracture of the steel perfobond shear connector, and no significant delamination or cracking of concrete was observed during the entire stages of the test. In addition, as discussed in more details later, a ductile behavior was exhibited in the loaddisplacement curve even after reaching the peak load. This type of failure mode is denoted as Type IV and was observed in specimens PO-6015-R, PO-5027-N, PO-5027-R, and PU5027-N.

Lastly, the cracking pattern of specimen PU-5027-R is exhibited in Figure 11. In contrast to Types III and IV, the ultimate failure mode of this specimen is not localized failures such as local crushing of concrete near the holes of the shear connector and yielding/fracture of the steel shear connector. Instead, the significant amounts of delamination and 

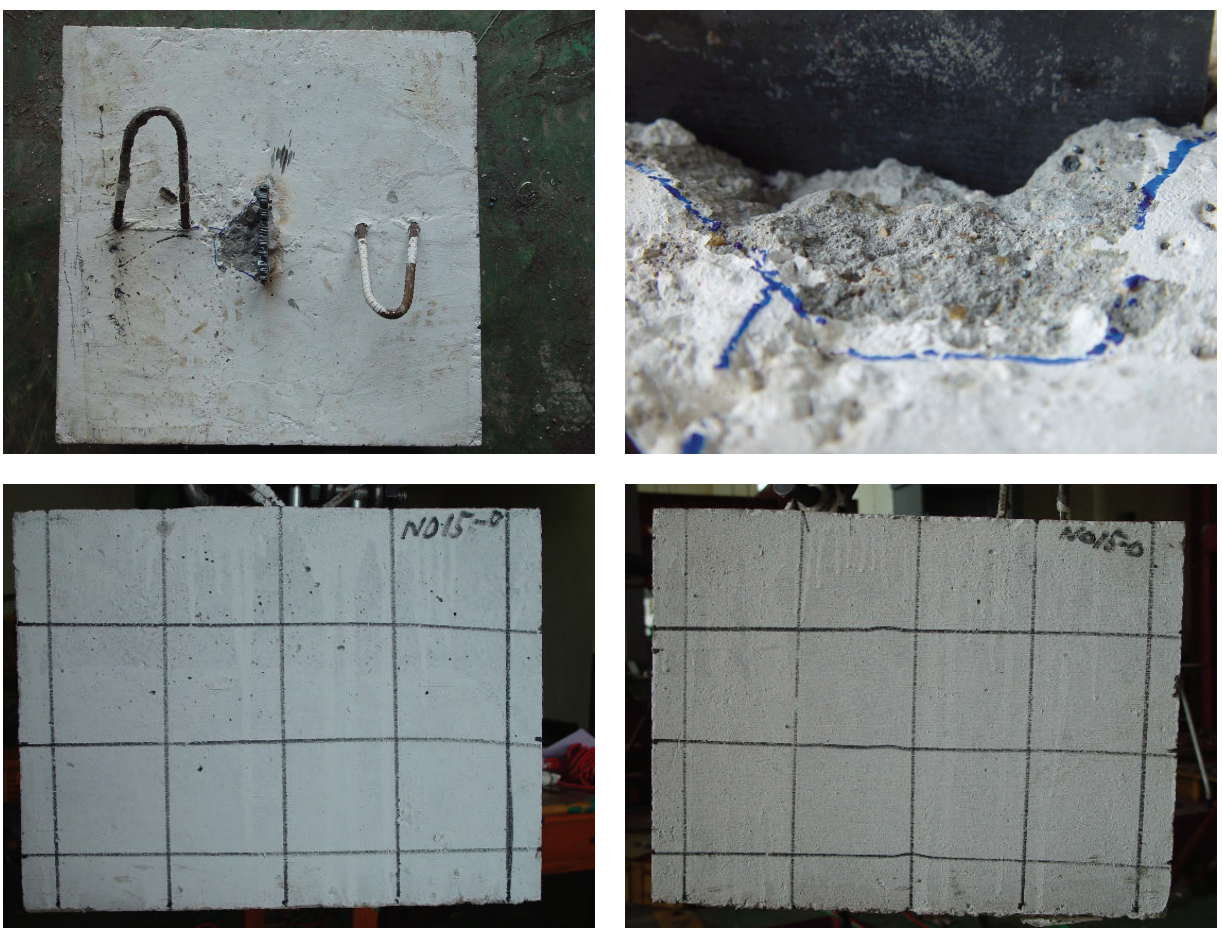

FIGURE 7: Failure mode of specimen PN-0015-N (Type I).
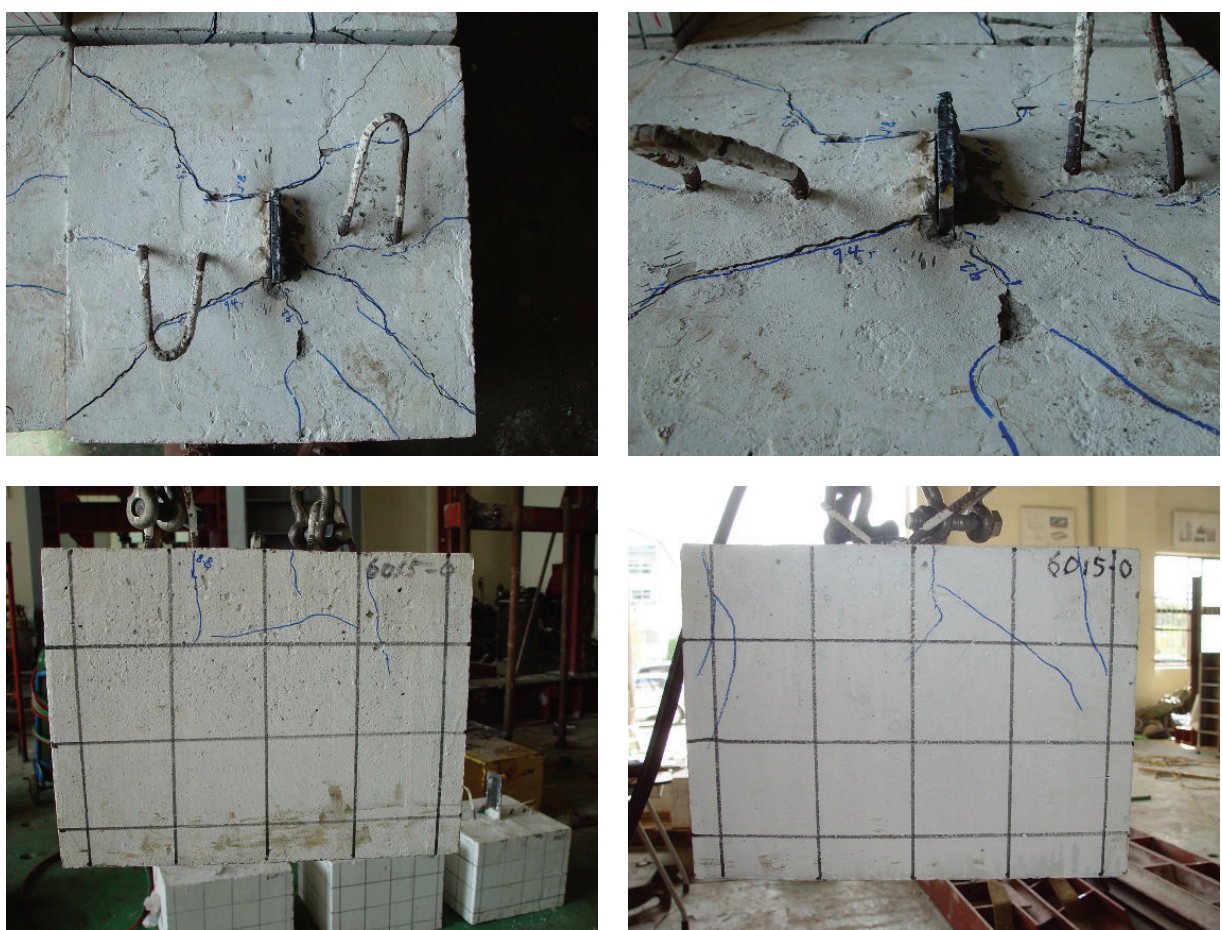

Figure 8: Failure mode of specimen PO-6015-N (Type II).

cracking of concrete were found in the entire specimen at ultimate stage as shown in the figure. This type of failure mode is categorized as Type $\mathrm{V}$ and was observed in specimen PU5027-R.
3.2. Effects of Test Parameters on the Shear Strength of Perfobond Shear Connectors. This section discusses the effects of test parameters such as the size of connector holes, existence of transverse rebars into the holes, embedment length of the 

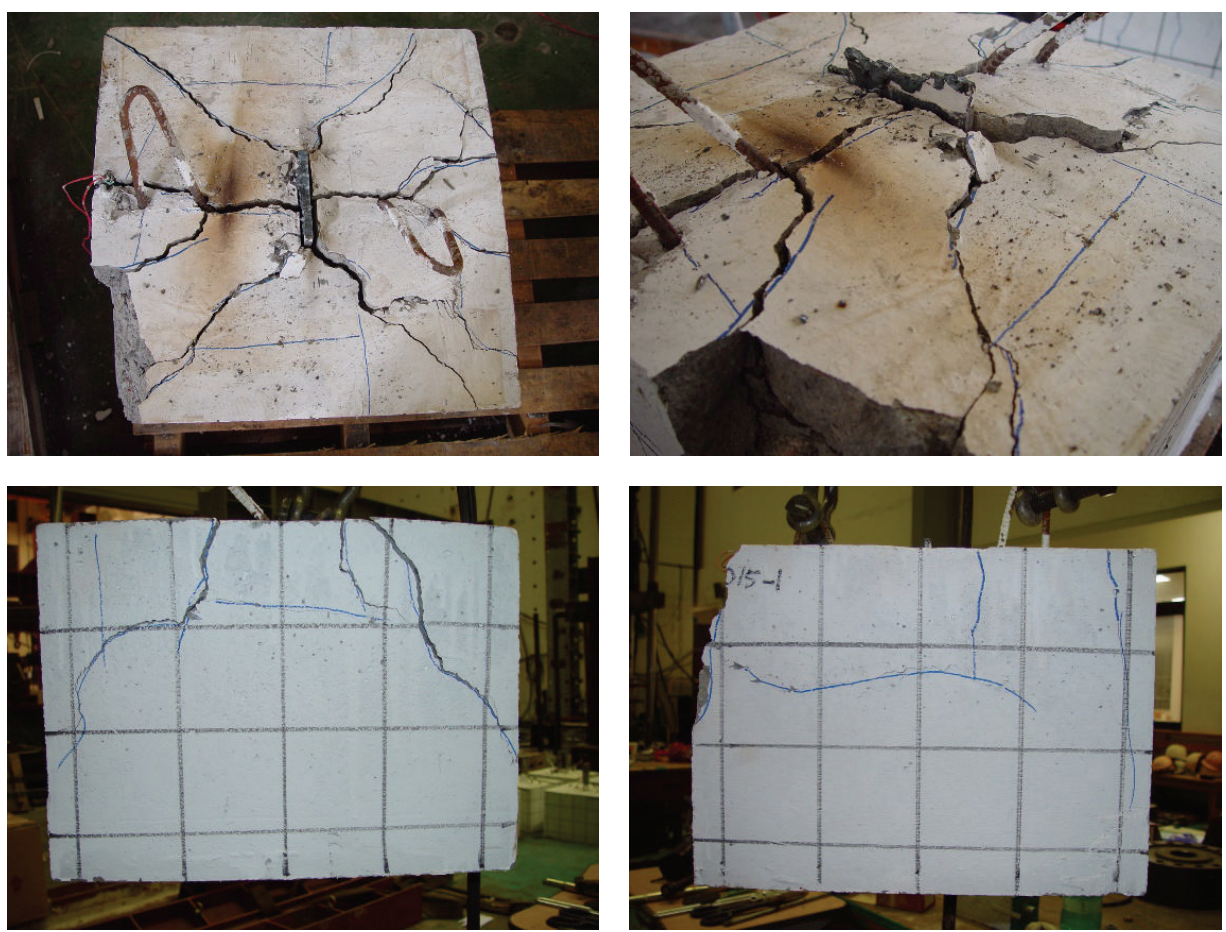

FIGURE 9: Failure mode of specimen PO-5015-R (Type III).
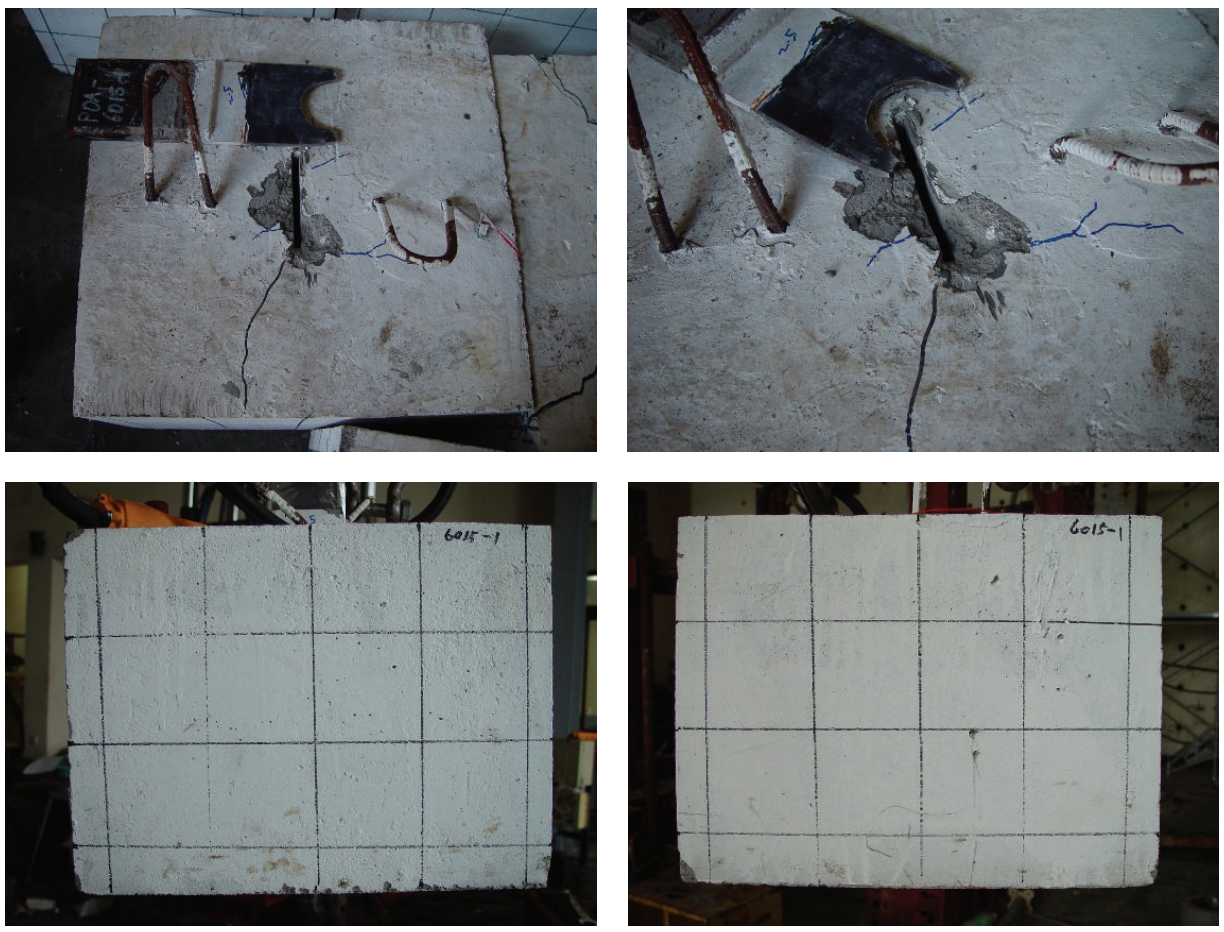

FIgURE 10: Failure mode of specimen PO-6015-R (Type IV).

shear connector, and shape of the connector hole on the shear strength of the perfobond connector.

Figure 12(a) shows the peak pull-out loads of the two sets of test specimens with different hole diameters, which are Series I and II listed in Table 3. The three test specimens
PN-0015-N, PO-5015-N, and PO-6015-N in Series I do not have any transverse rebars passing through the connector holes. It can be noticed from the results of these specimens that two test specimens with 50 and $60 \mathrm{~mm}$ hole diameters (PO-5015-N and PO-6015-N, resp.) retain the shear strength 

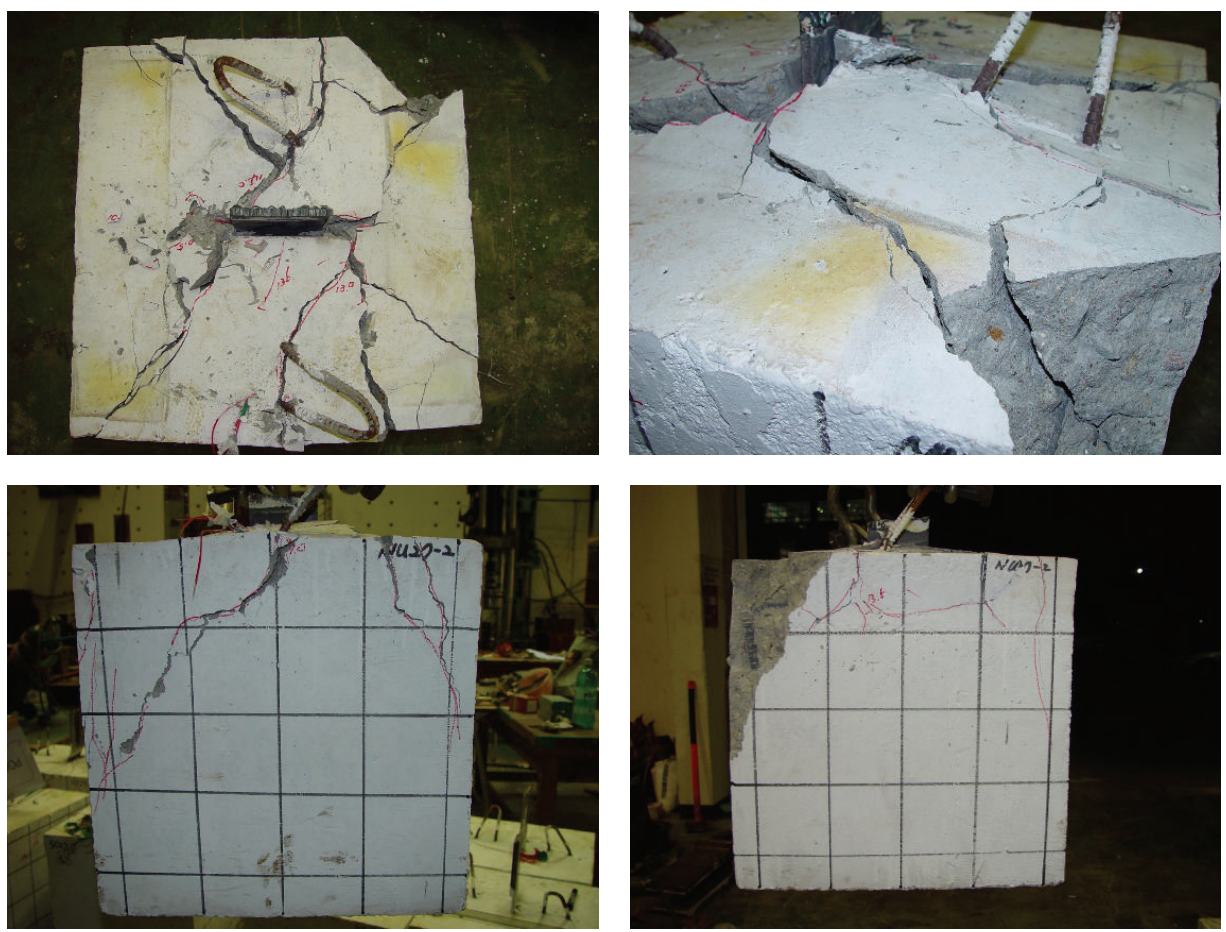

FIgURE 11: Failure mode of specimen PU-5027-R (Type V).

approximately 6 times higher than the one without any holes (PN-0015-N). This indicates that the existence of holes in the shear connector enables the dowel action of concrete inside the hole, resulting in the improvement of the shear resistance capacity of the connector. However, the peak pull-out loads of specimens PO-5015-N and PO-6015-N are almost equal to each other; thus, there seems to be a limit in the shear resistance capacity of the perfobond connector that can be improved by increasing the hole size.

The three test specimens in Series 2, which are PO4015-R, PO-5015-R, and PO-6015-R, have a transverse rebar passing through the connector hole. Their results in the figure show that the peak pull-out loads of the two test specimens with 40 and $50 \mathrm{~mm}$ hole diameter (PO-4015-R and PO-5015$\mathrm{R}$, resp.) are almost equal and the specimen with $60 \mathrm{~mm}$ hole diameter (PO-6015-R) retains shear resistance approximately $25 \%$ higher than those of the first two specimens. This may be attributed to the fact that a relatively large hole size of the specimen PO-6015-R helps the transverse rebar to be effectively integrated into the surrounding concrete, which eventually leads to the enhancement of the shear resistance capacity. In addition, it can be observed from Figure 6(b) that the initial stiffness of Series II specimens is increased with increasing the hole diameter.

The effect of the transverse rebar on the shear strength of the perfobond connector can be identified from the results of Figure 12(b). It plots the peak pull-out loads of the three sets of specimens reinforced with transverse rebars, which have different hole diameters $\left(d_{\text {hole }}\right)$ and embedment lengths $\left(l_{e}\right)$ such as PO-5015-N and PO-5015-R, PO-6015-N and PO$6015-\mathrm{R}$, and PO-5027-N and PO-5027-R. The results of the figure indicate that the existence of the transverse rebars enhances the peak pull-out load except the set of PO-5015-N and PO-5015-R. In addition, as can be seen from the comparison between Figures 6(a) and 6(b), it is helpful for retaining a significant level of ductility after reaching the peak load. The decrease of the peak pull-out load shown in the set of PO-5015-N and PO-5015-R seems to happen since specimen does not have sufficient space around the transverse rebar and the integration between the rebar and concrete is not fully achieved.

Figure 12(c) shows the effect of embedment length on the peak pull-out strength for the two sets of test specimens with and without transverse rebars, which are PO-5015-N and PO5027-N and PO-5015-R and PO-5027-R. The results of the figure indicate that, in both cases of the specimen sets, the peak pull-out load is increased at least by $50 \%$ by increasing the embedment length from $150 \mathrm{~mm}$ to $270 \mathrm{~mm}$. This confirms that the increase of embedment length is greatly helpful to improve the shear resistance capacity of the perfobond connector. In addition, the test results show that the peak pull-out loads of the specimens with transverse rebars are not always greater than those of the ones without transverse rebars. This may be attributed to the fact that only a single specimen was tested for each test parameter; thus, more tests may be required for the same test parameter to clarify this issue.

The effect of the shape of perfobond holes on the peak pull-out load can be evaluated from Figure 12(d). It plots the peak pull-out loads of the two specimen sets, which are PO5027-N and PO-5027-R and PU-5027-N and PU-5027-R. In the case of the second set of which specimens have open holes in the perfobond connector the peak pull-out load of 


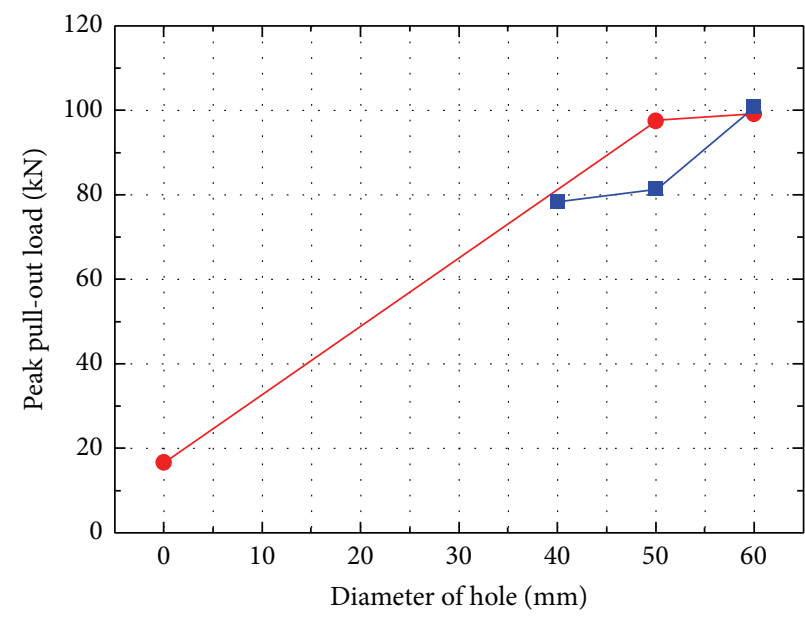

- Specimens without transverse rebars - Specimens with transverse rebars

(a) Size of connector holes

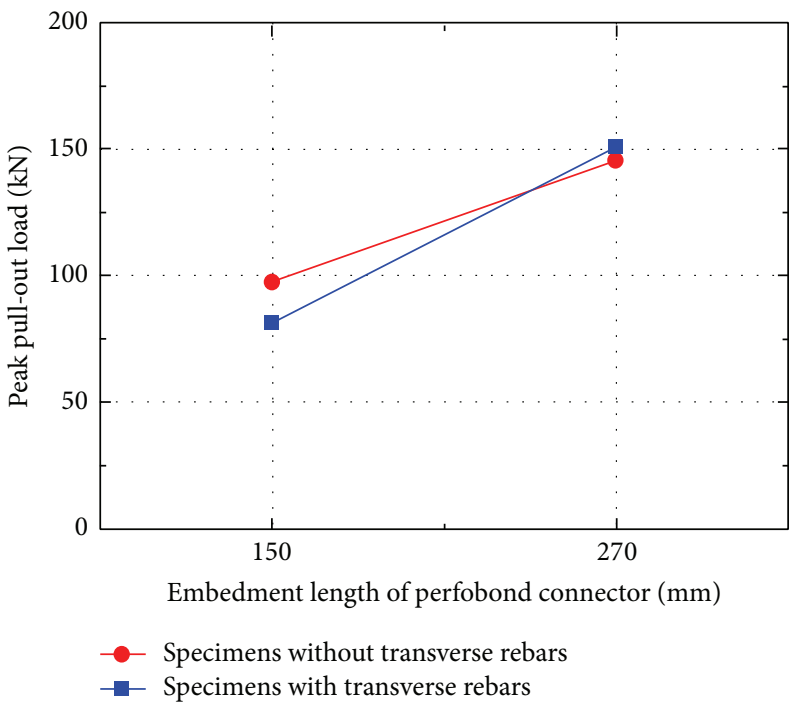

(c) Embedment length of perfobond connector

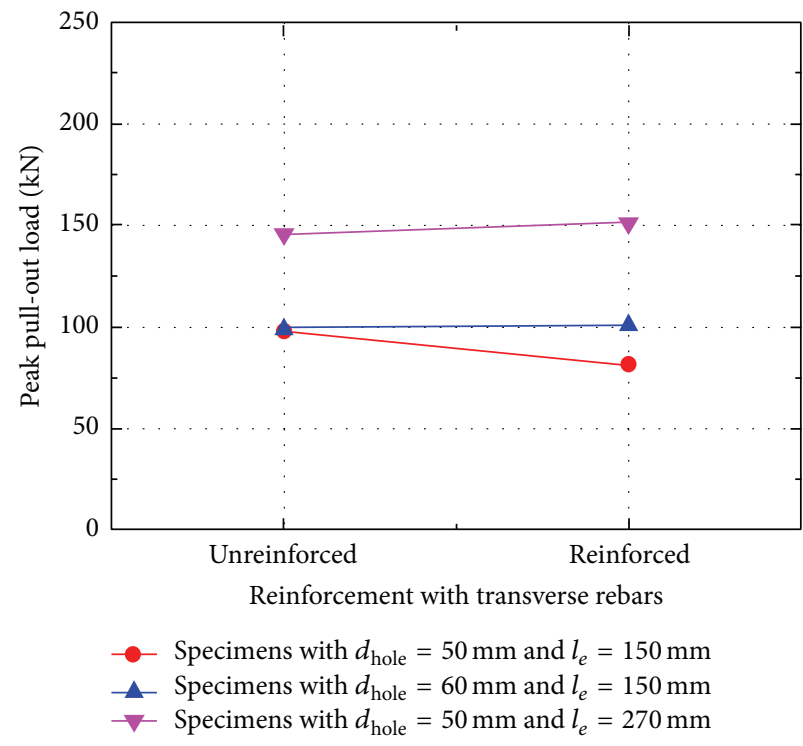

(b) Existence of transverse rebars

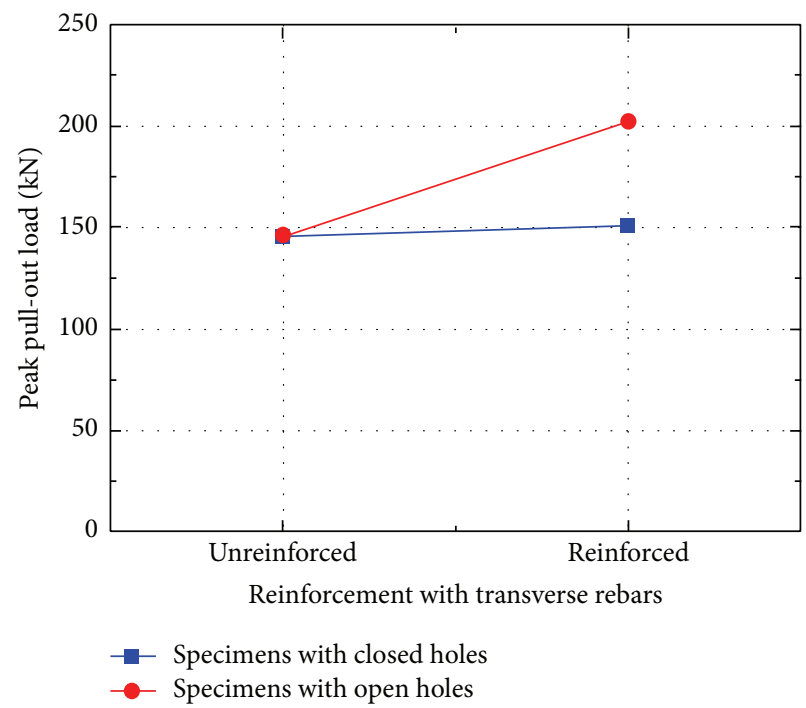

(d) Shape of connector hole

FIGURE 12: Effects of test parameters on the shear strength of perfobond shear connectors.

specimen PU-5027-R is approximately $30 \%$ greater than that of specimen PU-5027-R, while this kind of a phenomenon is not observed in the case of the first set. This seems to happen because the test specimen with open holes has a larger crosssectional area as shown in Figure 4; thus, it can retain a higher shear resistance capacity than the one with closed holes if its perfobond connector is fully anchored into the concrete cube with the help of transverse rebars.

\section{Conclusions}

In this study, we proposed a new type of the perfobond shear connector, which can be used to strengthen the steel pile cap embedded into the structure foundation, and evaluated its pull-out resistance capacity by performing a test on ten specimens. The main conclusions of this paper are as follows.

(1) The perfobond shear connector proposed in this study can retain the peak pull-out load up to 6 times higher than the one without any holes. This indicates that the existence of holes in the shear connector enables the dowel action of concrete inside the hole, resulting in the improvement of the shear resistance capacity of the connector.

(2) The size of the holes in the perfobond shear connector should be sufficiently large enough to guarantee that transverse rebars are integrated into the surrounding 
concrete, leading to the enhancement of the shear resistance capacity.

(3) In general, the existence of the transverse rebars enhances the peak pull-out load and is helpful for retaining a significant level of ductility after reaching the peak load.

(4) The increase of embedment length is greatly helpful to improve the shear resistance capacity of the perfobond connector.

(5) The perfobond shear connector with open holes may retain higher shear strength capacity than the one with closed holes if it is fully anchored into the concrete cube with the help of transverse rebars.

\section{Conflict of Interests}

The authors declare that there is no conflict of interests regarding the publication of this paper.

\section{Acknowledgment}

The corresponding author of this paper acknowledges the support from the Basic Science Research Program through the National Research Foundation of Korea (NRF) funded by the Ministry of Science, ICT \& Future Planning (Grant no. 2013R1A1A1076011).

\section{References}

[1] ACI Committee 318, Building Code Requirements for Structural Concrete (ACI 318-11) and Commentary, American Concrete Institute, Farmington Hills, Mich, USA, 2011.

[2] Eurocode 2: Design of Concrete Structures-Part 1-1: General Rules and Rules for Buildings, BS EN 1992-1-1, British Standard Institution, London, UK, 2004.

[3] W. Zellner, "Recent designs of composite bridges and a new type of shear connectors," in Proceedings of the ASCE/IABSE Engineering Foundation Conference on Composite Construction, pp. 240-252, Henniker, NH, USA, 1987.

[4] B. M. Sara and M. S. Bahram, "Perfobond shear connector for composite construction," Engineering Journal, vol. 39, no. 1, pp. 2-12, 2002.

[5] M. R. Veldanda and M. U. Hosain, "Behaviour of perfobond rib shear connectors: push-out tests," Canadian Journal of Civil Engineering, vol. 19, no. 1, pp. 1-10, 1992.

[6] E. C. Oguejiofor and M. U. Hosain, "Behaviour of perfobond rib shear connectors in composite beams: full-size tests," Canadian Journal of Civil Engineering, vol. 19, no. 2, pp. 224-235, 1992.

[7] E. C. Oguejiofor and M. U. Hosain, "A paramatic study of perfobond rib shear connectors," Canadian Journal of Civil Engineering, vol. 21, pp. 614-625, 1994.

[8] E. C. Oguejiofor and M. U. Hosain, "Numerical analysis of pushout specimens with perfobond rib connectors," Computers \& Structures, vol. 62, no. 4, pp. 617-624, 1997.

[9] J. Machacek and J. Studnicka, "Perforated shear connectors," Steel and Composite Structures, vol. 2, no. 1, pp. 51-66, 2002.

[10] I. Valente and P. J. S. Cruz, "Experimental analysis of Perfobond shear connection between steel and lightweight concrete," Jour- nal of Constructional Steel Research, vol. 60, no. 3-5, pp. 465479, 2004.

[11] H.-Y. Kim and H.-B. Koo, "Composite behavior of perfobond rib shear connector for steel-concrete decks," Journal of the Korean Society of Civil Engineers, vol. 26, no. 1, pp. 91-97, 2006 (Korean).

[12] ASTM International, "Standard test method for compressive strength of cylindrical concrete specimens," ASTM Standard C39/C39M-11, ASTM International, 2011. 

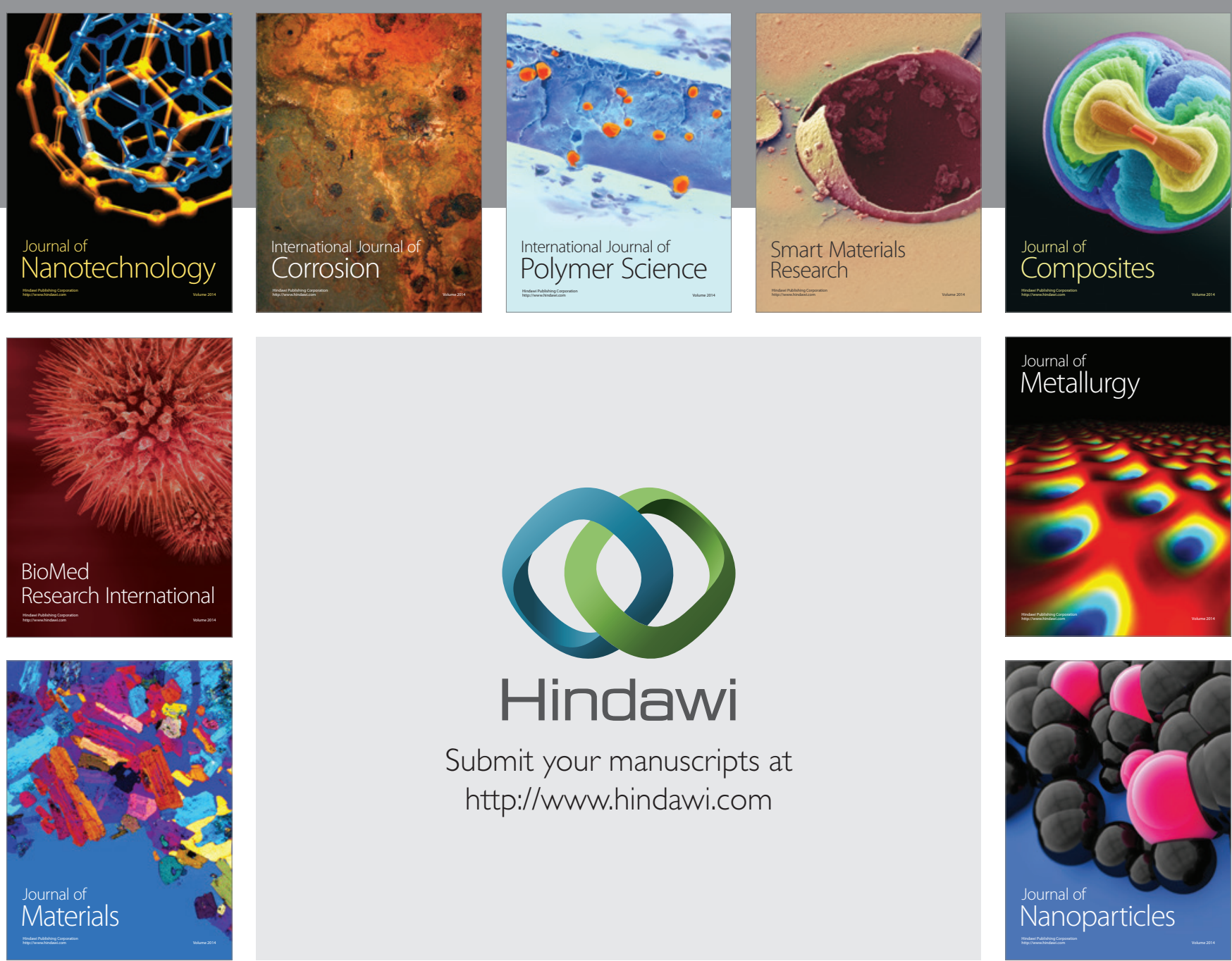

\section{Hindawi}

Submit your manuscripts at

http://www.hindawi.com

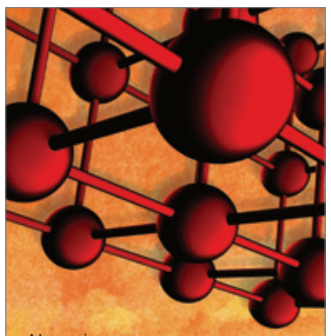

Materials Science and Engineering
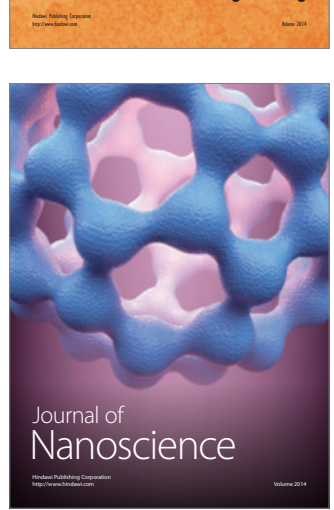
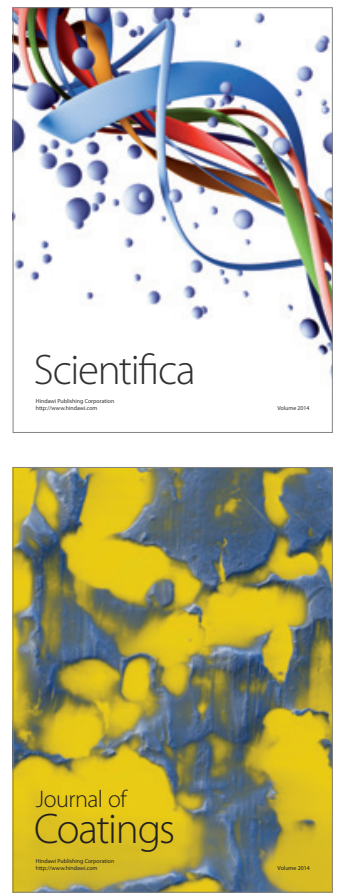
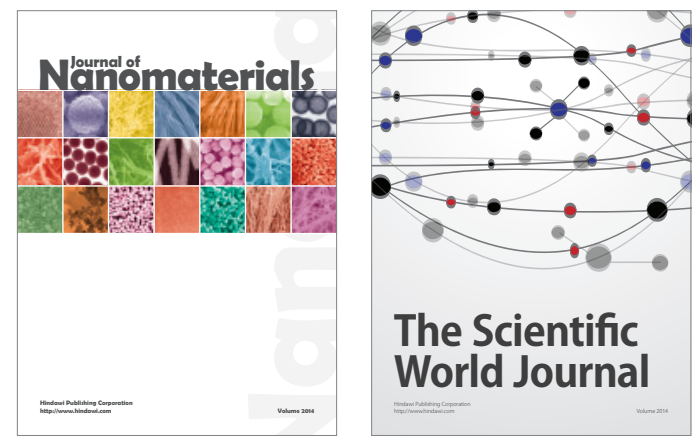

The Scientific World Journal
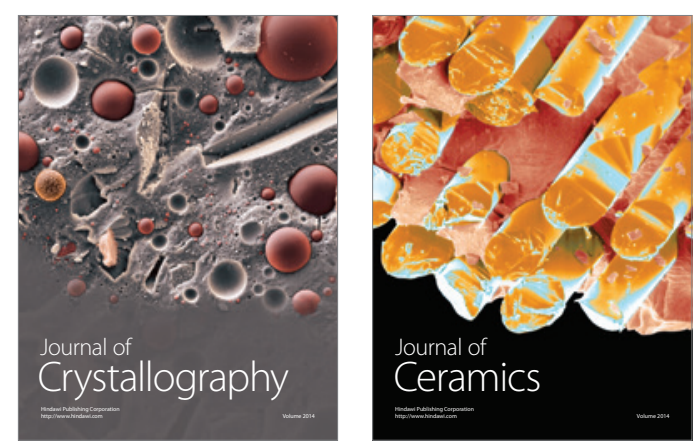
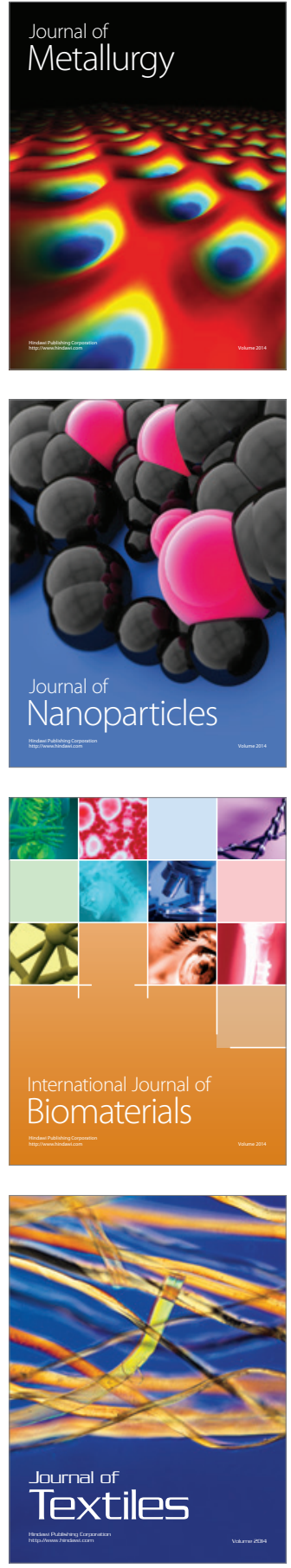